\title{
Photocatalytic Oxidation of Chlorantraniliprole, Imidacloprid, Pirimicarb, Thiamethoxam and Their Main Photoreaction InterMediates as Impacted by Water Matrix Composition under UVA-LED Exposure
}

\author{
Marina Aliste ${ }^{1, *}$, Isabel Garrido ${ }^{1}$, Gabriel Pérez-Lucas ${ }^{2}\left(\mathbb{D}\right.$, Simón Navarro ${ }^{2} \mathbb{D}$ and José Fenoll ${ }^{1, *(\mathbb{D})}$ \\ 1 Sustainability and Quality Group of Fruit and Vegetable Products, Murcia Institute of Agri-Food Research \\ and Development, C/Mayor s/n. La Alberca, 30150 Murcia, Spain; isabel.garrido3@carm.es \\ 2 Department of Agricultural Chemistry, Geology and Pedology, Faculty of Chemistry, University of Murcia, \\ Campus Universitario de Espinardo, 30100 Murcia, Spain; gpl2@um.es (G.P.-L.); snavarro@um.es (S.N.) \\ * Correspondence: marina.aliste@carm.es (M.A.); jose.fenoll@carm.es (J.F.); Tel.: +34-968366680 (M.A.); \\ +34-968366798 (J.F.)
}

Citation: Aliste, M.; Garrido, I.; Pérez-Lucas, G.; Navarro, S.; Fenoll, J. Photocatalytic Oxidation of Chlorantraniliprole, Imidacloprid, Pirimicarb, Thiamethoxam and Their Main Photoreaction InterMediates as Impacted by Water Matrix Composition under UVA-LED Exposure. Catalysts 2021, 11, 609. https://doi.org/10.3390/catal11050609

Academic Editors: Laura Bergamonti and Pier Paolo Lottici

Received: 21 April 2021

Accepted: 8 May 2021

Published: 10 May 2021

Publisher's Note: MDPI stays neutra with regard to jurisdictional claims in published maps and institutional affiliations.

Copyright: (c) 2021 by the authors. Licensee MDPI, Basel, Switzerland. This article is an open access article distributed under the terms and conditions of the Creative Commons Attribution (CC BY) license (https:/ / creativecommons.org/licenses/by/ $4.0 /)$.
Abstract: Processes on wastewater treatment plants (WWTP) are not always efficient for pollutant removal. A new, low-cost, and effective technology is needed. In this work, the photocatalytic degradation of four insecticides, chlorantraniliprole, imidacloprid, pirimicarb, and thiamethoxam, has been examined in different water matrices (irrigation water, leaching waters, and WWTP effluent). Lab experiments were conducted with $\mathrm{TiO}_{2}$ and $\mathrm{ZnO}$, as photocatalysts, with and without $\mathrm{Na}_{2} \mathrm{~S}_{2} \mathrm{O}_{8}$ as an oxidant, exposed to UVA irradiation with LED lamps. Previously, different loadings of $\mathrm{TiO}_{2}$ and $\mathrm{ZnO}$ were assessed on the disappearance kinetics of the different insecticides to know the optimal efficiency. The effect of water matrices, susceptible to being contaminated with the target insecticides, was discussed when the photocatalytic system $\mathrm{TiO}_{2} / \mathrm{Na}_{2} \mathrm{~S}_{2} \mathrm{O}_{8}$ was applied. The abatement of their main transformation products (TPs) was also monitored during the studied photoperiods. A total of 13 TPs were detected in the different water matrices studied. All of them were formed and eliminated during the photoperiod, except thiamethoxam urea which was present from the beginning of the experiments due to its hydrolysis in water. In conclusion, UVA-LED lamps are a good source to carry out heterogeneous photocatalysis in WWTP, since its high efficiency, low-cost, long lifetime, and effectiveness on pollutant removal.

Keywords: insecticides; heterogeneous photocatalysis; UV-LED lamps; irrigation water; leaching water; WWTP effluent

\section{Introduction}

In addition to water scarcity, the presence of a wide range of pollutants in wastewater have triggered the search of new, low-cost, and effective technologies that allow for reusing and recycling these waters in many countries [1]. Wastewater treatment plants (WWTP) use different processes, such as sedimentation, coagulation, volatilization, biodegradation, or sorption, to eliminate toxic contaminants, including pathogens, nutrients, or suspended solids, from wastewater [2]. However, these processes are not always efficient to remove pesticides and others organic biorecalcitrant pollutants [3]. The physicochemical properties of pesticides and the composition of water matrix are key factors having an important impact on the removal of these compounds in water $[3,4]$.

AOPs are the most studied and applied processes for the depletion of organic contaminants in water. Advanced oxidation processes (AOPs) are based on the formation of hydroxyl radicals $\left(\mathrm{HO}^{\bullet}\right)$ that have the ability to oxidize $\left(\mathrm{E}_{0}=2.8 \mathrm{eV}\right)$ organic molecules by a non-selective attack $[5,6]$. Among AOPs, heterogeneous photocatalysis using semiconductor materials such as $\mathrm{TiO}_{2}$ and $\mathrm{ZnO}$ has received the attention of the scientific community 
due to their photochemical properties and low cost [7,8]. Thus, Teixeira et al. [8], for instance, reused $\mathrm{TiO}_{2}$ and $\mathrm{ZnO}$ nanoparticles through an ecofriendly and cost-effective process for water treatment. Semiconductor materials can be irradiated by photons of energy equal or higher to its band gap energy $\left(E_{g}\right)$, generating electron/hole pairs $\left(\mathrm{e}^{-} / \mathrm{h}^{+}\right)$ on the catalyst surface. The $\mathrm{e}^{-} / \mathrm{h}^{+}$formed can generate hydroxyl $\left(\mathrm{HO}^{\bullet}\right)$ and others, such as superoxide anion $\left(\mathrm{O}_{2}{ }^{-}\right)$and hydridodioxygen $\left(\mathrm{HO}_{2}{ }^{\bullet}\right)$, radicals that have the ability to mineralize almost any organic molecule [7]. The $\mathrm{Eg}$ of $\mathrm{TiO}_{2}$ and $\mathrm{ZnO}$ is approximately 3.0 and $3.1 \mathrm{eV}$, respectively, therefore, the activation of these pure photocatalysts can only be carried out under UV light [9]. In addition to this, the use of oxidants improves the efficiency of the catalysts in these reactions. Persulfate $\left(\mathrm{S}_{2} \mathrm{O}_{8}{ }^{2-}\right)$ is a powerful oxidizing agent, since it decomposes in $\mathrm{SO}_{4}{ }^{\bullet-}$ radicals by the action of UV light and the electrons formed by the photocatalyst. This radical anion has a high oxidation potential $\left(\mathrm{E}_{0}=2.6 \mathrm{eV}\right)$ similar to $\mathrm{HO}^{\bullet}$ [7]. The semiconductor based photocatalytic degradation of pesticides has been described in the recent literature thoroughly [10]. This process contributes efficiently to remove biorecalcitrant pesticides from water, which are chemically stable and resistant to biodegradation. It is considered as a promising and environmentally friendly technique for many researchers [11]. The photocatalytic oxidation process is known to be an eco-friendly tool used for the transformation of toxic and hazardous pollutants, like pesticides, into $\mathrm{CO}_{2}, \mathrm{H}_{2} \mathrm{O}$, and inorganic mineral salts by mineralization of the parent compounds; instead of relocating them as it occurs with conventional (physical, chemical and/or biological) processes used for the treatment and reuse of water [12].

Medium and low-pressure mercury lamps are the UV radiation sources commonly used for photocatalytic oxidation of organic pollutants [13-17]. However, the toxicity of mercury has led the search for alternatives mercury-free UV sources, such as UV light emitting diodes (UV-LED) [18]. LED is a semiconductor device that transform energy into light. Different semiconductors, like GaN with an emitting central wavelength of $356 \mathrm{~nm}$, or InGaN for longer UV wavelength, have been used [19].

In the last years, UV-LED lamps have been used for the photocatalytic degradation of various organic contaminants in water [16,18,20-22]. It is due to the advantages of this type of UV source, such as the absence of mercury, low cost, long lifetime, high quantum efficiency, monochromatic emission in a range of wavelength, easy handling, small volume and high stability, robustness and flexibility [23-28]. Heterogeneous photocatalysis using $\mathrm{TiO}_{2}$ and UVA-LED is the most frequently applied method for the degradation of organic pollutants, mainly dyes, pharmaceutical compounds, and pesticides [18,29]. However, $\mathrm{ZnO}$ has been little investigated [30,31].

Bearing in mind the above mentioned, more research is necessary to find an efficient, suitable, and eco-friendly alternative for tackling the elimination of organic pollutants in water. We have assessed in this work the photocatalytic degradation of four insecticides, chlorantraniliprole (anthranilic diamide), imidacloprid (neonicotinoid), pirimicarb (carbamate), and thiamethoxam (neonicotinoid), widely used for crop protection and found in surface- and groundwater resources [32,33]. For this purpose, $\mathrm{TiO}_{2}$ and $\mathrm{ZnO}$ have been used as photocatalysts in tandem with $\mathrm{Na}_{2} \mathrm{~S}_{2} \mathrm{O}_{8}$ and UVA-LED lamps in different type of waters (irrigation, leaching and wastewater effluent). The abatement of their main transformation products (TPs) has been also monitored during the studied photoperiod.

\section{Results and Discussion}

\subsection{Assessment of the Optimum Catalysts Loading for the Photocatalytic Degradation in} Pure Water

The impact of catalyst concentration on the degradation rates of the studied insecticides for the election of the most appropriate loading to be used in the incoming experiments was previously evaluated. The catalyst and oxidant load, photoreactor geometry, and light irradiation condition the photocatalytic efficiency [34]. In this paper, these parameters were fixed, except the catalysts load, which was studied. A battery of tests was performed separately for $\mathrm{TiO}_{2}\left(0-500 \mathrm{mg} \mathrm{L}^{-1}\right)$ and $\mathrm{ZnO}\left(0-500 \mathrm{mg} \mathrm{L}^{-1}\right)$. As observed in previous works $[7,29,35,36]$, the evolution of rate constants, with the addition of the 
different catalyst loads, follow similar behavior. Degradation rates of the four insecticides were increasing as the catalyst loading increased. The greater catalyst load, the freer active sites available for photons [37]. There was a point where a maximum value of rate constant is reached (200 and $350 \mathrm{mg} \mathrm{L}^{-1}$ for $\mathrm{TiO}_{2}$ and $\mathrm{ZnO}$, respectively) and, next, the efficiency of the process started to decrease fairly. An excess of catalyst in the reaction medium causes a light scattering and screening effect that inhibits the effectiveness of the systems $[7,10]$. For $\mathrm{TiO}_{2}$ assays, rate constants ranged from $0.007 \mathrm{~min}^{-1}$ for $\mathrm{CH}$ (without $\mathrm{TiO}_{2}$ load) to $1.721 \mathrm{~min}^{-1}$ for PI (with $200 \mathrm{mg} \mathrm{L}^{-1}$ of $\mathrm{TiO}_{2}$ ). In the case of experiments with $\mathrm{ZnO}$, rate constants ranged from $0.007 \mathrm{~min}^{-1}$ for $\mathrm{CH}$ (without $\mathrm{ZnO}$ load) to $1.554 \mathrm{~min}^{-1}$ for PI (with $350 \mathrm{mg} \mathrm{L}^{-1}$ of $\mathrm{ZnO}$ ). The greater rate constants were reached with $200 \mathrm{mg} \mathrm{L}^{-1}$ of $\mathrm{TiO}_{2}$ and $350 \mathrm{mg} \mathrm{L}^{-1}$ of $\mathrm{ZnO}$, when $200 \mathrm{mg} \mathrm{L}^{-1}$ of PS were fixed, for the four insecticides. The rate constant order was: $\mathrm{PI}>\mathrm{IM} \geq \mathrm{TH}>\mathrm{CH}$ (Figure S1, Supplementary material).

Figure 1 shows a comparison between the optimized systems $\mathrm{TiO}_{2} / \mathrm{PS}$ and $\mathrm{ZnO} / \mathrm{PS}$ and the simple systems with $\mathrm{TiO}_{2}, \mathrm{ZnO}$ and PS alone or only UV radiation (photolysis). First, only PI seems to be slightly affected by the UV radiation. PI suffers a fast degradation when is irradiated with UVA lamps [38]. At the end of the photolysis experiment $26 \%$ of PI removal was achieved, while for the rest of the insecticides UV radiation removed less than $4 \%$ after $60 \mathrm{~min}$ of reaction. When we focused on the simple systems, degradation curves of insecticides did not follow a clear pattern. For $\mathrm{CH}$, the three degradation curves had a similar shape, for IM and PI the order was $\mathrm{TiO}_{2}>\mathrm{PS}>\mathrm{ZnO}$ while, for $\mathrm{TH}$ the degradation rate with PS was noticeable better than with $\mathrm{TiO}_{2}$ or $\mathrm{ZnO}$. This tells us that the chemical structure of each compound can affect to the degradation in a same studied system.

Those systems in which catalysts and oxidant were combined, the degradation rates improved significantly for all insecticides compared with those systems where only catalysts or oxidant were used. The use of electron acceptors such as persulfate $\left(\mathrm{S}_{2} \mathrm{O}_{8}{ }^{2-}\right)$ or peroxymonosulfate $\left(\mathrm{HSO}_{5}{ }^{-}\right)$enhance the formation of $\mathrm{HO}$ and inhibit the $\mathrm{e}^{-} / \mathrm{h}^{+}$pair recombination [39]. The principle of AOPs is the generation of strongly oxidizing radical species, such as $\mathrm{HO}^{\bullet}\left(\mathrm{E}_{0}=1.9-2.7 \mathrm{~V}\right.$ vs. NHE), in the presence of a semiconductor oxide. In addition, when an oxidant as $\mathrm{Na}_{2} \mathrm{~S}_{2} \mathrm{O}_{8}$ is also used, sulfate radical anion $\mathrm{SO}_{4}{ }^{\bullet-}$ $\left(\mathrm{E}_{0}=2.5-3.1 \mathrm{~V}\right.$ vs. NHE$)$ and more $\mathrm{HO}^{\bullet}$ are generated, among other. Both radical species take part equally in reactions at neutral $\mathrm{pH}[40,41]$. The scientific literature presents a large number of rigorous research works related with the activation of PS [40-43]. Degradation rate constants (Table S1, Supplementary Material) shows the system ZnO/PS being slightly faster than $\mathrm{TiO}_{2} / \mathrm{PS}$ for $\mathrm{CH}, \mathrm{IM}$, and $\mathrm{TH}$. As has been already discussed in previous works [29,44-47], $\mathrm{TiO}_{2}$ offers more advantages from the economic and environmental point of view than $\mathrm{ZnO}$, despite producing faster insecticides abatement. If advantages of using $\mathrm{TiO}_{2}$ are added to those using UV-LED lamps, an attractive and eco-friendly method would be developed. $\mathrm{TiO}_{2} / \mathrm{PS}$ was the chosen photocatalytic system to carry out the discussion in different water matrices susceptible to being contaminated with the target insecticides. 


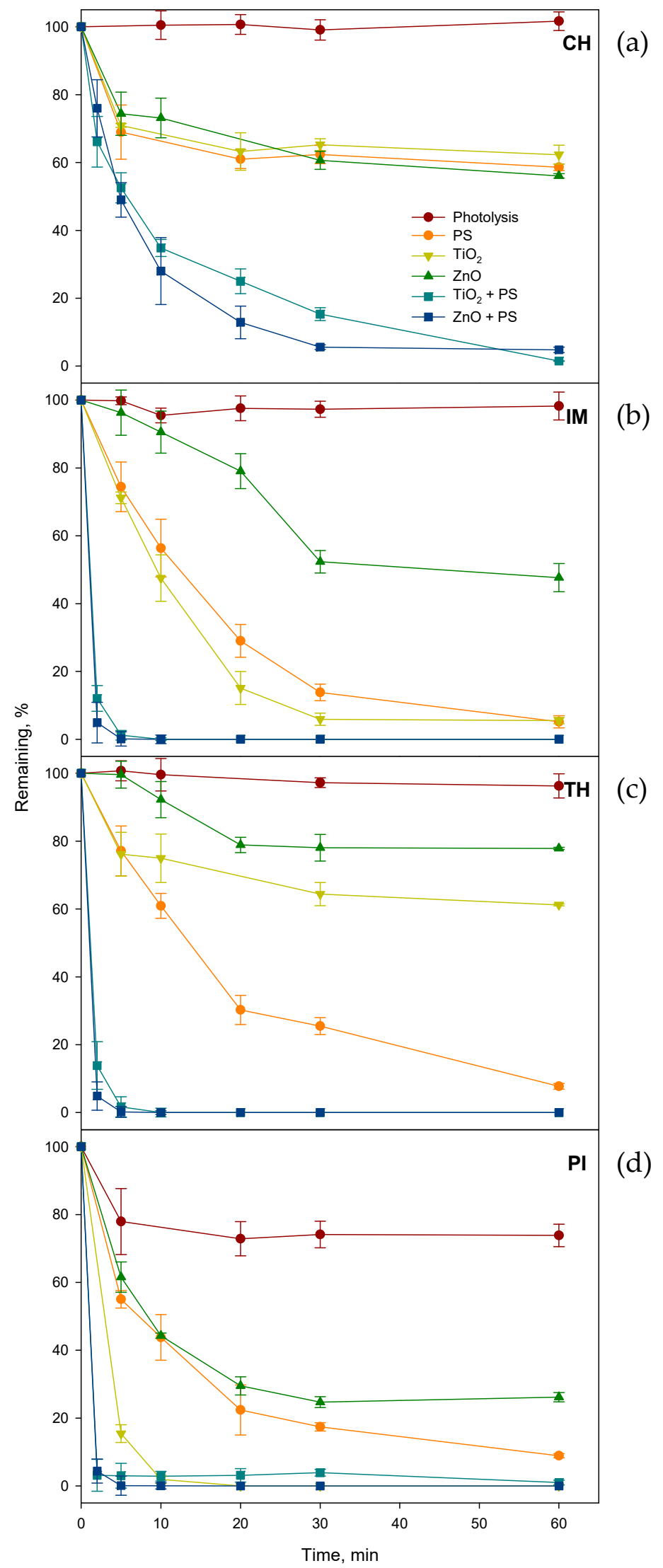

Figure 1. Photocatalytic processes comparison in pure water spiked at $1 \mathrm{mg} \mathrm{L}^{-1}$ of target compounds $\left([\mathrm{PS}]=200 \mathrm{mg} \mathrm{L}^{-1} ;\left[\mathrm{TiO}_{2}\right]=200 \mathrm{mg} \mathrm{L}^{-1} ;[\mathrm{ZnO}]=350 \mathrm{mg} \mathrm{L}^{-1}\right.$ ). (a) Chlorantraniliprole; (b) Imidacloprid; (c) Thiamethoxam; (d) Pirimicarb. 


\subsection{Photocatalytic Activity in Real Matrices}

Insecticides photocatalytic removal $(\mathrm{CH}, \mathrm{IM}, \mathrm{PI}$, and $\mathrm{TH})$ was studied in different water matrices. Those waters, which were spiked with the studied insecticides at $1.0 \mathrm{mg} \mathrm{L}^{-1}$, were irrigation water (IW), leaching water with high (LW-H), and low DOC (LWL) content and an effluent from a wastewater treatment plant (WWTPe). The combined system $\mathrm{TiO}_{2} / \mathrm{PS}$, above chosen, was used for the experiments with UV-LED exposure. In addition, the main TPs derived from the studied insecticides (Table S2, Supplementary Material) were also monitored.

The half-life data of each insecticide (calculated as $t_{1 / 2}=\ln 2 / k_{a p p}$ ) are a good parameter to compare their removal in different water matrices. Compared to distilled water (where $\mathrm{t}_{1 / 2}$ were less than $1 \mathrm{~min}$; except for $\mathrm{CH}$ which was $11 \mathrm{~min}$ ), $\mathrm{LW}-\mathrm{H}$ was the most affected by the matrix effect with half-lives $163,245,430$ and 396 times higher for $\mathrm{CH}$, IM, $\mathrm{PI}$, and TH, respectively (Table 1). We noticed a full shortage of efficiency in the essays conducted in LW-H. As expected, we observed lower pesticide decrease on the processes carried out in those water matrices with higher DOC. The general trend in the degradation efficiency of insecticide studied followed the order: IW $>$ WWTPe $>$ LW-L $>$ LW-H, which could be associated to the complexity of real tested water.

Table 1. Degradation rate constant $\left(\mathrm{k}_{\mathrm{app}}, \mathrm{min}^{-1}\right)$ and half-lives $\left(\mathrm{t}_{1 / 2}, \mathrm{~min}\right)$ of each insecticide in each tested water $(n=3)$.

\begin{tabular}{ccccccccc}
\hline \multirow{2}{*}{ Water } & \multicolumn{2}{c}{ Chlorantraniliprole } & \multicolumn{2}{c}{ Imidacloprid } & \multicolumn{2}{c}{ Pirimicarb } & \multicolumn{2}{c}{ Thiamethoxam } \\
\cline { 2 - 9 } & $\mathbf{k}_{\text {app }}$ & $\mathbf{t}_{\mathbf{1 / 2}}$ & $\mathbf{k}_{\text {app }}$ & $\mathbf{t}_{\mathbf{1 / 2}}$ & $\mathbf{k}_{\mathbf{a p p}}$ & $\mathbf{t}_{\mathbf{1} \mathbf{2}}$ & $\mathbf{k}_{\mathbf{a p p}}$ & $\mathbf{t}_{\mathbf{1 / 2}}$ \\
\hline $\mathrm{DW}$ & 0.065 & 11 & 1.027 & 0.7 & 1.721 & 0.4 & 0.951 & 0.7 \\
$\mathrm{IW}$ & 0.007 & 105 & 0.053 & 13 & 0.123 & 6 & 0.049 & 14 \\
LW-H & 0.000 & 1733 & 0.004 & 165 & 0.004 & 173 & 0.002 & 289 \\
LW-L & 0.004 & 161 & 0.025 & 28 & 0.020 & 35 & 0.020 & 35 \\
WWTPe & 0.004 & 193 & 0.024 & 29 & 0.054 & 13 & 0.023 & 30 \\
\hline
\end{tabular}

Lado Ribeiro et al. [4] listed the effect of those components (organic and/or inorganic) that affect the degradation processes: (1) light attenuation by solid suspended, (2) consumption of $\mathrm{HO}^{\bullet}$ (among others oxidizing species) by natural organic matter (NOM), (3) scavenging from formatted radicals, with lower oxidation potential, from those anions present in waters (bicarbonate, sulfate, chloride or nitrate), and (4) competition for active sites on catalyst surface between all organic and inorganic species present in water. To sum up, the presence of non-target compounds can compete with target compounds in the degradation process. As showed Table S3 (Supplementary Material), $\mathrm{NO}_{2}{ }^{-}$and $\mathrm{PO}_{4}{ }^{3-}$ were below detection limit in all cases. All target compounds have chlorine and nitrogen atoms on their chemical structure, except PI that does not have chlorine (Table S4, Supplementary Material). Thus, a weak increase in $\mathrm{Cl}^{-}$and $\mathrm{NO}_{3}{ }^{-}$concentrations was observed during the experiment as a consequence of mineralization. The increase in EC observed in all experiments is mainly correlated with the increase in $\mathrm{SO}_{4}{ }^{2-}$ appeared because the $\mathrm{S}_{2} \mathrm{O}_{8}{ }^{2-}$ added $\left(\mathrm{SO}_{4}{ }^{\bullet-}+\mathrm{H}_{2} \mathrm{O} \rightarrow \mathrm{SO}_{4}{ }^{2-}+\mathrm{HO}^{\bullet}+\mathrm{H}^{+}\right)$[32], additionally to the weak increase in $\mathrm{Cl}^{-}$and $\mathrm{NO}_{3}{ }^{-}$. $\mathrm{HCO}_{3}{ }^{-}$concentration was reduced due to its conversion into $\mathrm{CO}_{2}$, from $19.6 \%$ to $92.0 \%$ with WWTPe and IW, respectively (Table S3, Supplementary Material). A weak decrease on $\mathrm{pH}$ values was observed likely due to the formation of some organic acids during the treatment. However, no significant differences $(p<0.05)$ were observed in $\mathrm{pH}$ value, which was circumneutral during the photo-processes.

Some inorganic ions, mainly $\mathrm{SO}_{4}{ }^{2-}, \mathrm{Cl}^{-}, \mathrm{NO}_{3}{ }^{-}$, and $\mathrm{HCO}_{3}{ }^{-}$, have a detrimental effect due to their capability to act as $\mathrm{HO}^{\bullet}$ scavengers. Consequently, the oxidizing capacity of the solution is decreased. Considering the water composition, the scavenging of $\mathrm{HO}^{\bullet}$ by these anions could cause the corresponding radicals but all of them with lower $\mathrm{E}_{0}$ than $\mathrm{HO}^{\bullet}[4,7,32,48]$. On the other hand, high concentration of DOC can decrease insecticide photodegradation. The sensitization effect is shadowed by the forceful filter effect (quench- 
ing) of some recalcitrant organic compounds such as humic substances [49]. They can operate as one of the most important absorbers of sunlight, especially in the UV-range and rapidly reacting with $\mathrm{HO}^{\bullet}$. In addition, humic substances can be easily adsorbed onto the semiconductor surface, competing for the reaction sites with target pollutants [50].

The aim of AOPs is not only the removal of the parent compounds, but also the degradation of reaction intermediates originated, because they can be more hazardous in some cases and their complete mineralization to $\mathrm{CO}_{2}, \mathrm{H}_{2} \mathrm{O}$ and mineral salts is difficult at certain times. What is expected of the TPs is that they form and disappear, completely, during the photoperiod. Figure 2 depict the photocatalytic abatement found for each insecticide, in all water tested, and the behavior of their detected TPs. At the end of the photoperiod, 85.2, 61.8, 60.1 and only $10.9 \%$ of CH removal in IW, WWTPe, LW-L and $\mathrm{LW}-\mathrm{H}$, respectively, were achieved (Figure 2a). $\mathrm{CH}$ removal in $\mathrm{LW}-\mathrm{H}$ was so slow that it was not possible to identify more than one TP: $\mathrm{CH}-1$, whose reduction could not be reached. However, in water matrices, with less than $10 \mathrm{mg} \mathrm{L}^{-1}$ of DOC, CH-2, CH-6 and CH-7 were additionally detected. On the contrary, $\mathrm{CH}-3$ was only detected when the degradation took place in LW-L, being all of them partially eliminated. Regarding to IM, PI and TH removal (Figure $2 \mathrm{~b}-\mathrm{d}$ ), once finished the photoperiod, a complete elimination (>99.7\%) in IW, LW-L and WWTPe matrices was noted. However, in LW-H, removal percentages were 61.0, 58.9, and $44.9 \%$ for IM, PI, and TH, respectively. Only IM-2 (hydroxy imidacloprid) was detected on IM removal in all tested waters (Figure 2b). In the same way that happened with $\mathrm{CH}$, IM-2 appeared since the beginning of the photoperiod, reached a high and decreased until its almost complete disappearance at $240 \mathrm{~min}$ of reaction. However, in $\mathrm{LW}-\mathrm{H}$, the high of IM-2 was not achieved at the end of the experiment and its decrease was not noted. Five TPs from PI described in Table S2 (Supplementary Material) were detected, at different amounts, in all studied water matrices; except PI-4 in LW-H, which was not detected (Figure 2c). PI-1 (desmethyl-formamido) was the most abundant in all cases, following by PI-5 (desmethyl). This suggests that the preferred degradation pathway starts forming the carbamate with a successive $\mathrm{N}$-dealkylation of the 2-dimethylamino group, as proposed Fenoll et al. [9]. For TH abatement, two TPs were detected: TH-1 and TH-2 (Figure 2d). TH-1 (clothianidin) appeared and disappeared during the photoperiod, except in $\mathrm{LW}-\mathrm{H}$, in consonance with TPs above mentioned. Exceptionally, TH-2 (thiamethoxam urea) was present from time zero in all water matrices (9528 \pm 425 u.a.) and disappeared with the same shape than its parent compounds. It was probably generated during the homogenization time in darkness before UV-A LED exposure because it is described as a mayor hydrolysis product of TH [51]. Regarding to DOC data, IW and LW-L suffered a decrease due to abatement of target pesticides and their main detected TPs, from 17.5 and $30.2(0 \mathrm{~min})$ to 13.1 and $24.1 \mathrm{mg} \mathrm{L}^{-1}(240 \mathrm{~min})$, respectively. DOC concentration evolution in WWTPe suffered a slightly not significant increase (from 12.8 at initial time to $13.3 \mathrm{mg} \mathrm{L}^{-1}$ at final time). In the case of $\mathrm{LW}-\mathrm{H}, \mathrm{DOC}$ concentration increases from 102.7 to $104.4 \mathrm{mg} \mathrm{L}^{-1}$ (initial and final reaction time, respectively) due to the no reached reduction of $\mathrm{CH}-1, \mathrm{IM}-2$ and TH-1 at the end of the experiments. To sum up, DOC data are a good complementary tool to indicate if an abatement of organic pollutants have been reached successfully. 


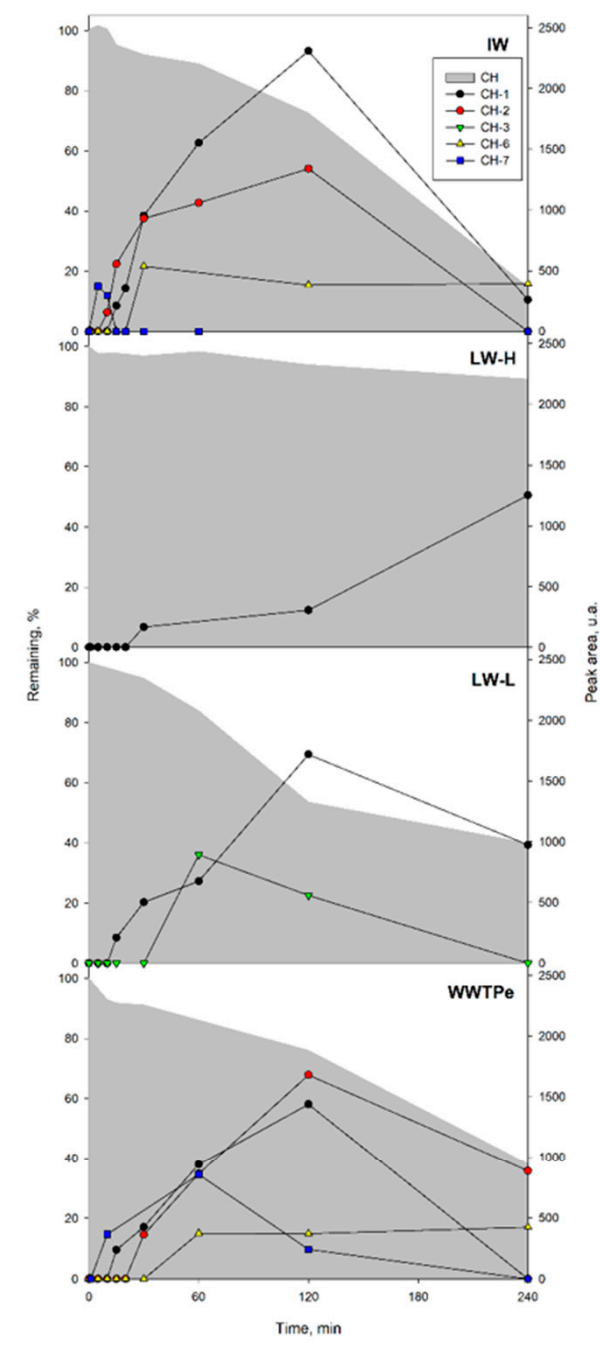

(a)

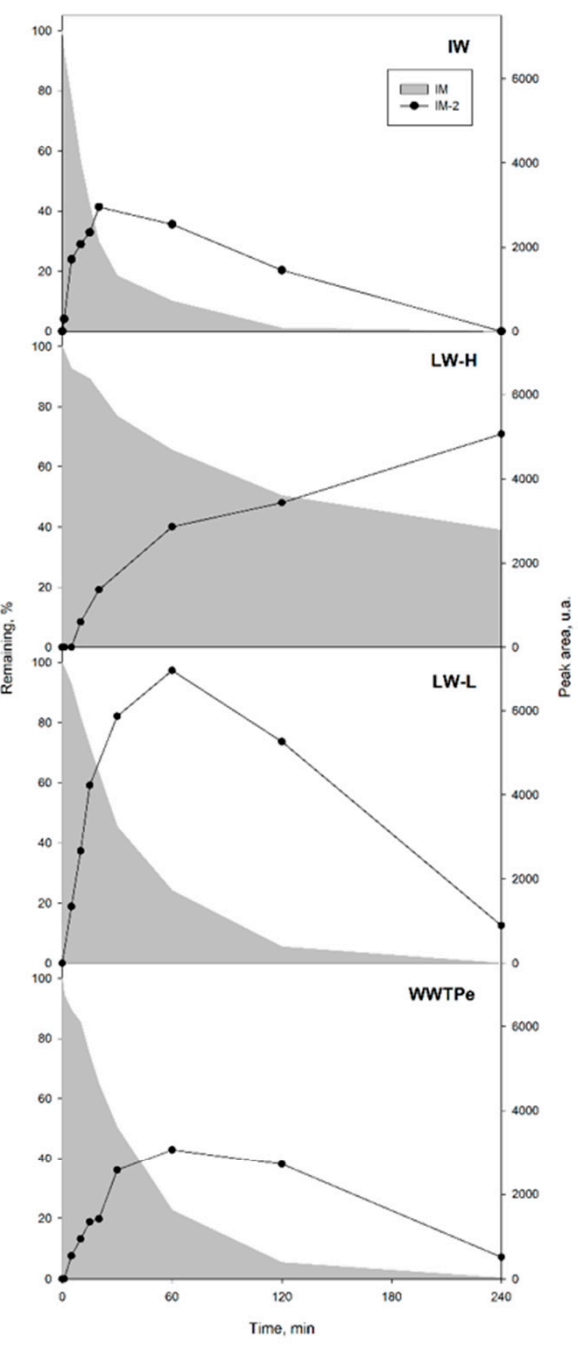

(b)

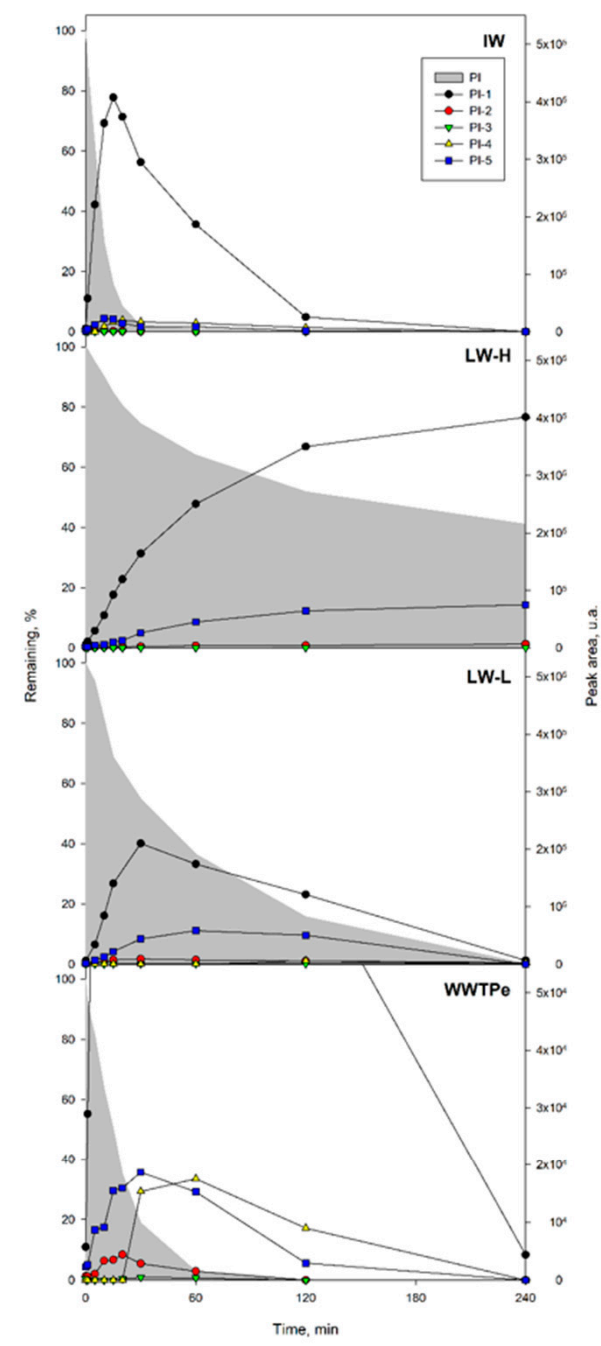

(c)

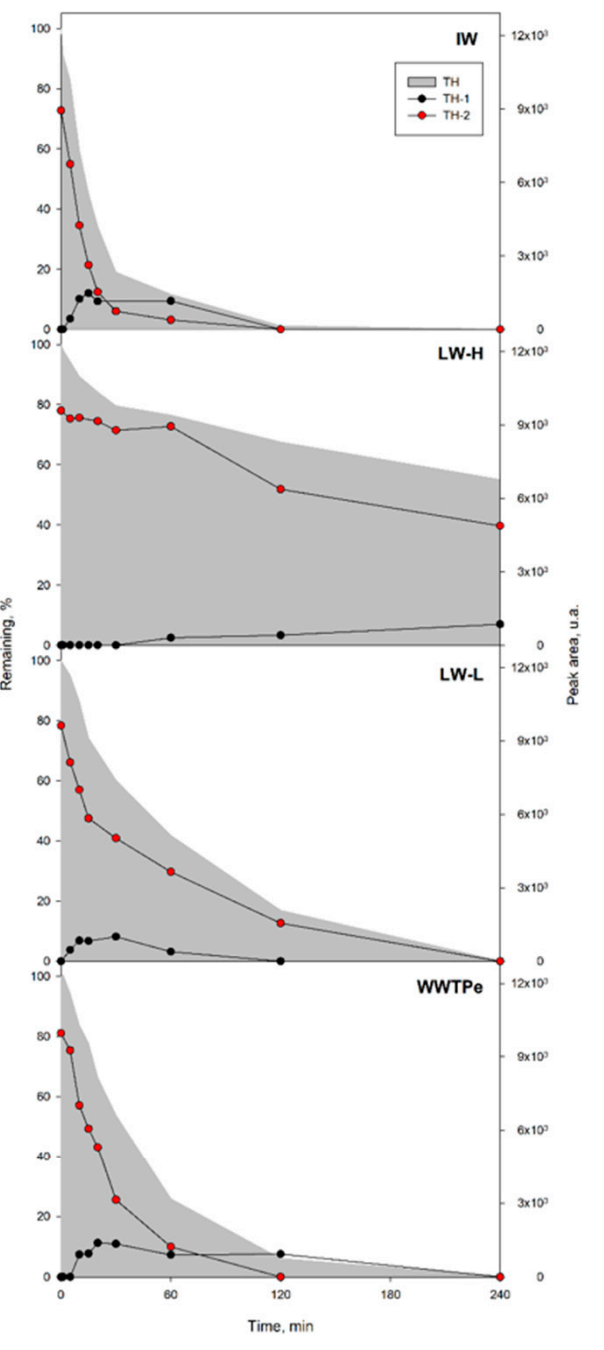

(d)

Figure 2. Degradation kinetics of (a) chlorantraniliprole; (b) imidacloprid; (c) pirimicarb; (d) thiamethoxam, spiked at $1 \mathrm{mg} \mathrm{L}^{-1}$, and their TPs (peak area data) during the UVA-LED photocatalytic process, in the studied water matrices. 


\section{Materials and Methods}

\subsection{Reagents}

Chlorantraniliprole $(\mathrm{CH})$, imidacloprid (IM), pirimicarb (PI), and thiamethoxam $(\mathrm{TH})$ analytical standards, all with purity $>97 \%$, were provided by Dr. Ehrenstorfer GmBh (Augsburg, Germany). Their main physicochemical properties are summarized in Table S4 (Supplementary Material) [52]. Commercial formulations of $\mathrm{CH}, \mathrm{IM}, \mathrm{PI}$, and $\mathrm{TH}$ were supplied by FitoDolores S.L. (Murcia, Spain). $\mathrm{TiO}_{2}$ Aeroxide P25 (99.5\% purity) and $\mathrm{ZnO}$ (99.9\% purity) catalysts, previously characterized by [53] were purchased from Nippon Aerosil Co Ltd. (Osaka, Japan) and Alfa Aesar (Karlsruhe, Germany), respectively. Different solvents, such as acetonitrile, and reagents, such as $\mathrm{Na}_{2} \mathrm{~S}_{2} \mathrm{O}_{8}$ and $\mathrm{NaCl}$ were purchased from Scharlab (Barcelona, Spain).

\subsection{Water Sources}

Irrigation water (IW; pH: 7.2; EC: $0.49 \mathrm{dS} \mathrm{m}^{-1}$; DOC: $3.7 \mathrm{mg} \mathrm{L}^{-1}$ ) was collected from the Tagus-Segura Water Transfer. Leaching water samples were generated by washing a clay-loam textured soil (30\% clay, $43 \%$ silt, $27 \%$ sand; $\mathrm{pH} 8.1$, OC: $0.96 \%$; EC: $4.8 \mathrm{dS} \mathrm{m}^{-1}$; alkalinity: $456 \mathrm{mg} \mathrm{CaCO}_{3} \mathrm{~kg}^{-1}$ ) through a disturbed polyvinyl chloride column $(30 \mathrm{~cm} \times 5 \mathrm{~cm}$ id) by washing it with deionized water. Two leachates of $900 \mathrm{~mL}$ of each one were collected. The first leachate (LW-H; pH: 7.4; EC: $1.13 \mathrm{dS} \mathrm{m}^{-1}$; DOC: $92.0 \mathrm{mg} \mathrm{L}^{-1}$ ) had a higher DOC content and EC than the second one (LW-L; pH: 7.3; EC: $0.35 \mathrm{dS} \mathrm{m}^{-1}$; DOC: $21.1 \mathrm{mg} \mathrm{L}^{-1}$ ). Finally, a real sample of wastewater effluent (WWTPe; $\mathrm{pH}$ : 7.2; EC: $2.69 \mathrm{dS} \mathrm{m}^{-1}$; DOC: $7.2 \mathrm{mg} \mathrm{L}^{-1}$ ) was collected from a WWTP placed in Murcia (SE of Spain).

\subsection{Photochemical Experiments}

Photocatalytic processes under lab-conditions were carried out using a photochemical reactor Photolab LED365-16/450-16c (APRIA Systems S.L., Cantabria, Spain), as formerly described Aliste et al. [29] (Figure S2, Supplementary Material). The total radiation intensity was $656.4 \mathrm{~W} \mathrm{~m}^{-2}$, at $365 \mathrm{~nm}$ of used source. Firstly, the effect of catalyst load on the photooxidation process of these insecticides was studied in pure water $\left(\mathrm{EC}<1 \mu \mathrm{S} \mathrm{cm}{ }^{-1} ; \mathrm{pH} 6.9\right.$ and DOC $<30 \mu \mathrm{g} \mathrm{L}^{-1}$ ). In each experiment, water was spiked with analytical standards of each insecticide at $1 \mathrm{mg} \mathrm{L}^{-1}$ and different concentrations of $\mathrm{TiO}_{2}\left(0-500 \mathrm{mg} \mathrm{L}^{-1}\right)$ and $\mathrm{ZnO}$ $\left(0-500 \mathrm{mg} \mathrm{L}^{-1}\right)$ were added to the solutions. The slurries were homogenized in darkness for $20 \mathrm{~min}$. After this time, $200 \mathrm{mg} \mathrm{L}^{-1}$ of $\mathrm{Na}_{2} \mathrm{~S}_{2} \mathrm{O}_{8}$ (PS) were added and slurries were exposed to UV-LED lamps for $60 \mathrm{~min}$. Different samples were collected during each photoprocess and the experiments were replicated three times. Additionally, both photolysis and only photocatalysis (without oxidant), experiments were carried out to compare with the experiments above mentioned.

The photochemical reactor was used, secondly, to perform photocatalytic removal of insecticides in different water matrices: irrigation- leaching water (at two level of dissolved organic carbon, DOC), and a WWTP effluent. All the water samples were spiked at $1 \mathrm{mg} \mathrm{L}^{-1}$, with the commercial formulations of the target insecticides. For the photocatalytic treatments with the different kinds of water using UV-LED lamps on the removal of four insecticides, $200 \mathrm{mg} \mathrm{L}^{-1}$ of $\mathrm{TiO}_{2}$ were added. $20 \mathrm{~min}$ of homogenization in darkness were needed before PS addition ( $\left.200 \mathrm{mg} \mathrm{L}^{-1}\right)$. Subsequently, samples were collected for $240 \mathrm{~min}$ of reaction time where they were exposed to UV irradiation. Each experiment was replicated three times.

\subsection{Analytical Measurements}

$\mathrm{CH}, \mathrm{IM}, \mathrm{PI}$, and TH residues from water were analyzed following the methodology proposed by Fenoll et al. [54]. Table S2 (Supplementary material) details the analytical conditions for each insecticide and their TPs already described by Fenoll et al. $[9,44,55]$.

DOC content was measured after filtering of water samples $(0.45 \mu \mathrm{m}$ nylon filter $)$ using a Multi N/C 3100 TOC Analyzer (Analytic Jena AG, Jena, Germany) connected to a NDIR detector $\left(950^{\circ} \mathrm{C}\right)$. Anions $\left(\mathrm{Cl}^{-}, \mathrm{NO}_{3}{ }^{-}, \mathrm{PO}_{4}{ }^{3-}, \mathrm{SO}_{4}{ }^{2-}, \mathrm{CO}_{3}{ }^{2-}\right.$, and $\left.\mathrm{HCO}_{3}{ }^{-}\right)$were 
analyzed using ion chromatography by means of an ion chromatograph, Dionex ICS-2100 (Thermo Scientific, Waltham, MA, USA), as previously specified [32].

\subsection{Determination of Kinetic Parameters}

Kinetic parameters of insecticide degradation were determined with the software Sigmaplot v.14.0 administered by Systat Software Inc. (San José, CA, USA). They were estimated using a single first-order kinetics [56] (1), where $C_{0}$ and $C_{t}$ are the insecticide concentration at initial time $\left(t_{0}\right)$ and a given time $t$, respectively, and $k_{a p p}$ is the apparent rate constant $\left(\mathrm{min}^{-1}\right)$.

$$
C_{t}=C_{0} e^{-k a p p t} \text { or } \ln \left(C_{0} / C_{t}\right)=k_{a p p} t
$$

\section{Conclusions}

High amounts of pesticide residues have been found in different wastewaters. The presence of these can considerably affect living beings and the environment, which is why it is necessary to eliminate them from the environment. What a good tool for an efficient photocatalytic system is a good quality of light. LED technology has revolutionized AOPs due to its significant advantages over conventional lamps, from an economic, useful, and environmentally friendly point of view. In this work, we studied the abatement of four insecticides and their transformation products in different water matrices by heterogeneous photocatalysis $\left(\mathrm{TiO}_{2} / \mathrm{Na}_{2} \mathrm{~S}_{2} \mathrm{O}_{8}\right)$ assisted by UV-LED radiation. The findings suggest that the degradation rates of pollutants will depend on the chemical composition of water matrices, the organic matter content being the greatest scavenger. Finally, the studied technology is necessary and possible to improve water quality, especially in WWTPs.

Supplementary Materials: The following are available online at https://www.mdpi.com/article/ $10.3390 /$ catal11050609/s1, Figure S1. Optimization of the photocatalytic process using different concentrations of $\mathrm{TiO}_{2}$ and $\mathrm{ZnO}\left(0-500 \mathrm{mg} \mathrm{L}^{-1}\right)$, with $200 \mathrm{mg} \mathrm{L}^{-1}$ of $\mathrm{Na}_{2} \mathrm{~S}_{2} \mathrm{O}_{8}$, Figure S2: Schematic drawing for the photochemical reactor Photolab LED365-16/450-16c (APRIA Systems S.L. Cantabria. Spain) used in experiments [29], Table S1: Kinetic parameters estimated for the photocatalytic degradation of insecticides at $1 \mathrm{mg} \mathrm{L}^{-1}(\mathrm{n}=3)$, Table S2: Analytical conditions of the studied insecticides and their transformation products by HPLC-MS ${ }^{2}$ [9,44,55], Table S3. Evolution of electric conductivity $\left(\mathrm{EC}, \mu \mathrm{S} \mathrm{cm}{ }^{-1}\right.$ ) and concentrations of inorganic anions $\left(\mathrm{mg} \mathrm{L}^{-1}\right)$ in different water matrices during the photochemical period, Table S4: Main physico-chemical properties of the insecticides studied.

Author Contributions: Conceptualization, M.A., S.N. and J.F.; methodology, M.A., I.G., G.P.-L., S.N and J.F.; validation, M.A., I.G. and G.P.-L.; formal analysis, M.A., S.N. and J.F.; investigation, M.A., S.N. and J.F.; resources, M.A., I.G., G.P.-L., S.N. and J.F.; data curation, M.A., S.N. and J.F.; writingoriginal draft preparation, M.A., S.N. and J.F.; writing—review and editing, M.A., I.G., G.P.-L., S.N. and J.F.; visualization, M.A., S.N. and J.F.; supervision, S.N. and J.F.; project administration, S.N. and J.F.; funding acquisition, S.N. and J.F. All authors have read and agreed to the published version of the manuscript.

Funding: The authors are grateful to the Ministry of Science and Innovation of Spain for financial support (Project PID2019-106648RB-I00/AEI/10.13039/501100011033) in the framework of the State Programs of Generation of Knowledge and Scientific and Technological Strengthening oriented to the Challenges of Society. The authors are also grateful for the financial support received by State Research Agency (Spain) and European Social Fund (Project RTA2015-00073-00-00, INIA 2017-2020).

Data Availability Statement: Data is contained within the article or supplementary material.

Acknowledgments: The authors appreciate the technical assistance of H. Jiménez, J. Cava, I. Garrido, M.V. Molina and E. Molina.

Conflicts of Interest: The authors declare no conflict of interest. The funders had no role in the design of the study; in the collection, analyses, or interpretation of data; in the writing of the manuscript, or in the decision to publish the results. 


\section{References}

1. Ternes, T.; Joss, A.; Oehlmann, J. Occurrence, fate, removal and assessment of emerging contaminants in water in the water cycle (from wastewater to drinking water). Water Res. 2015, 72, 1-2. [CrossRef] [PubMed]

2. Rout, P.R.; Zhang, T.C.; Bhunia, P.; Surampalli, R.Y. Treatment technologies for emerging contaminants in wastewater treatment plants: A review. Sci. Total Environ. 2021, 753, 141990. [CrossRef] [PubMed]

3. Yang, Y.; Ok, Y.S.; Kim, K.H.; Kwon, E.E.; Tsang, Y.F. Occurrences and removal of pharmaceuticals and personal care products (PPCPs) in drinking water and water/sewage treatment plants: A review. Sci. Total Environ. 2017, 596-597, 303-320. [CrossRef] [PubMed]

4. Lado Ribeiro, A.R.; Moreira, N.F.F.; Li Puma, G.; Silva, A.M.T. Impact of water matrix on the removal of micropollutants by advanced oxidation technologies. Chem. Eng. J. 2019, 363, 155-173. [CrossRef]

5. Miklos, D.B.; Remy, C.; Jekel, M.; Linden, K.G.; Drewes, J.E.; Hübner, U. Evaluation of advanced oxidation processes for water and wastewater treatment-A critical review. Water Res. 2018, 139, 118-131. [CrossRef]

6. Rizzo, L.; Malato, S.; Antakyali, D.; Beretsou, V.G.; Đolić, M.B.; Gernjak, W.; Heath, E.; Ivancev-Tumbas, I.; Karaolia, P.; Lado Ribeiro, A.R.; et al. Consolidated vs new advanced treatment methods for the removal of contaminants of emerging concern from urban wastewater. Sci. Total Environ. 2019, 655, 986-1008. [CrossRef] [PubMed]

7. Ahmed, S.; Rasul, M.G.; Brown, R.; Hashib, M.A. Influence of parameters on the heterogeneous photocatalytic degradation of pesticides and phenolic contaminants in wastewater: A short review. J. Environ. Manag. 2011, 92, 311-330. [CrossRef]

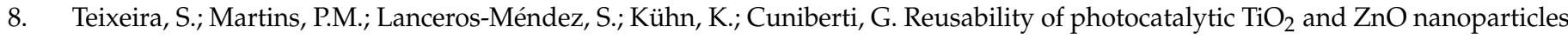
immobilized in poly(vinylidene difluoride)-co-trifluoroethylene. Appl. Surf. Sci. 2016, 384, 497-504. [CrossRef]

9. Fenoll, J.; Garrido, I.; Hellín, P.; Flores, P.; Vela, N.; Navarro, S. Photocatalytic oxidation of pirimicarb in aqueous slurries containing binary and ternary oxides of zinc and titanium. J. Photochem. Photobiol. A Chem. 2015, 298, 24-32. [CrossRef]

10. Vaya, D.; Surolia, P.K. Semiconductor based photocatalytic degradation of pesticides: An overview. Environ. Technol. Innov. 2020, 20, 101128. [CrossRef]

11. Reddy, P.V.L.; Kim, K.H. A review of photochemical approaches for the treatment of a wide range of pesticides. J. Hazard. Mater. 2015, 285, 325-335. [CrossRef]

12. Al-Ghouti, M.A.; Al-Kaabi, M.A.; Ashfaq, M.Y.; Da'na, D.A. Produced water characteristics, treatment and reuse: A review. J. Water Process. Eng. 2019, 28, 222-239. [CrossRef]

13. Gomez-Ruiz, B.; Ribao, P.; Diban, N.; Rivero, M.J.; Ortiz, I.; Urtiaga, A. Photocatalytic degradation and mineralization of perfluorooctanoic acid (PFOA) using a composite $\mathrm{TiO}_{2}-\mathrm{rGO}$ catalyst. J. Hazard. Mater. 2018, 344, 950-957. [CrossRef]

14. Sousa, M.A.; Gonçalves, C.; Pereira, J.H.O.S.; Vilar, V.J.P.; Boaventura, R.A.R.; Alpendurada, M.F. Photolytic and TiO 2 -assisted photocatalytic oxidation of the anxiolytic drug lorazepam (Lorenin ${ }^{\circledR}$ pills) under artificial UV light and natural sunlight: A comparative and comprehensive study. Sol. Energy 2013, 87, 219-228. [CrossRef]

15. Sousa, M.A.; Lacina, O.; Hrádková, P.; Pulkrabová, J.; Vilar, V.J.P.; Gonçalves, C.; Boaventura, R.A.R.; Hajšlová, J.; Alpendurada, M.F. Lorazepam photofate under photolysis and $\mathrm{TiO}_{2}$-assisted photocatalysis: Identification and evolution profiles of by-products formed during phototreatment of a WWTP effluent. Water Res. 2013, 47, 5584-5593. [CrossRef]

16. Tapia-Tlatelpa, T.; Buscio, V.; Trull, J.; Sala, V. Performance analysis and methodology for replacing conventional lamps by optimized LED arrays for photocatalytic processes. Chem. Eng. Res. Des. 2020, 156, 456-468. [CrossRef]

17. Zawadzki, P.; Kudlek, E.; Dudziak, M. Kinetics of the Photocatalytic Decomposition of Bisphenol A on Modified Photocatalysts. J. Ecol. Eng. 2018, 19, 260-268. [CrossRef]

18. Jo, W.K.; Tayade, R.J. New generation energy-efficient light source for photocatalysis: LEDs for environmental applications. Ind. Eng. Chem. Res. 2014, 53, 2073-2084. [CrossRef]

19. Matafonova, G.; Batoev, V. Recent advances in application of UV light-emitting diodes for degrading organic pollutants in water through advanced oxidation processes: A review. Water Res. 2018, 132, 177-189. [CrossRef]

20. Davididou, K.; Nelson, R.; Monteagudo, J.M.; Durán, A.; Expósito, A.J.; Chatzisymeon, E. Photocatalytic degradation of bisphenol-A under UV-LED, blacklight and solar irradiation. J. Clean. Prod. 2018, 203, 13-21. [CrossRef]

21. Ghosh, J.P.; Achari, G.; Langford, C.H. Design and evaluation of a UV LED Photocatalytic Reactor Using Anodized TiO 2 Nanotubes. Water Environ. Res. 2016, 88, 785-791. [CrossRef] [PubMed]

22. Hossaini, H.; Moussavi, G.; Farrokhi, M. The investigation of the LED-activated $\mathrm{FeFNS}-\mathrm{TiO}_{2}$ nanocatalyst for photocatalytic degradation and mineralization of organophosphate pesticides in water. Water Res. 2014, 59, 130-144. [CrossRef]

23. Muramoto, Y.; Kimura, M.; Nouda, S. Development and future of ultraviolet light-emitting diodes: UV-LED will replace the UV lamp. Semicond. Sci. Technol. 2014, 29, 084004. [CrossRef]

24. Tokode, O.; Prabhu, R.; Lawton, L.A.; Robertson, P.K.J. UV LED source for heterogeneous photocatalysis. In Environmental Photochemistry Part III, 1st ed.; Bahnemann, D.W., Robertson, P.K.J., Eds.; Springer: Heidelberg, Germany, 2015; pp. 159-179. [CrossRef]

25. Eskandarian, M.R.; Choi, H.; Fazli, M.; Rasoulifard, M.H. Effect of UV-LED wavelengths on direct photolytic and TiO 2 photocatalytic degradation of emerging contaminants in water. Chem. Eng. J. 2016, 300, 414-422. [CrossRef]

26. Chen, D.H.; Ye, X.; Li, K. Oxidation of PCE with a UV LED photocatalytic reactor. Chem. Eng. Technol. 2005, 28, 95-97. [CrossRef]

27. Bowker, C.; Sain, A.; Shatalov, M.; Ducoste, J. Microbial UV fluence-response assessment using a novel UV-LED collimated beam system. Water Res. 2011, 45, 2011-2019. [CrossRef] 
28. Khan, M.A. AlGaN multiple quantum well based deep UV LEDs and their applications. Phys. Status Solidi A Appl. Res. 2006, 203, 1764-1770. [CrossRef]

29. Aliste, M.; Garrido, I.; Pérez-Lucas, G.; Flores, P.; Hellín, P.; Navarro, S.; Fenoll, J. Appraisal of water matrix on the removal of fungicide residues by heterogeneous photocatalytic treatment using UV-LED lamp as light source. Environ. Sci. Pollut. Res. 2020. [CrossRef] [PubMed]

30. Bousmaha, M.; Bezzerrouk, M.A.; Kharroubi, B.; Akriche, A.; Naceur, R.; Hattabi, I.; Sandjak-Eddine, K. Enhanced photocatalysis by depositing $\mathrm{ZnO}$ thin film in the inner wall of glass tube. Optik 2019, 183, 727-731. [CrossRef]

31. Hossaini, H.; Moussavi, G.; Farrokhi, M. Oxidation of diazinon in cns-ZnO/LED photocatalytic process: Catalyst preparation, photocatalytic examination, and toxicity bioassay of oxidation by-products. Sep. Purif. Technol. 2017, 174, 320-330. [CrossRef]

32. Aliste, M.; Pérez-Lucas, G.; Garrido, I.; Fenoll, J.; Navarro, S. Mobility of insecticide residues and main intermediates in a clay-loam soil, and impact of leachate components on their photocatalytic degradation. Chemosphere 2021, 274, 129965. [CrossRef]

33. Aliste, M.; Garrido, I.; Flores, P.; Hellín, P.; Pérez-Lucas, G.; Navarro, S.; Fenoll, J. Photocatalytic degradation of four insecticides and their main generated transformation products in soil and pepper crop irrigated with reclaimed agro-wastewater under natural sunlight. J. Hazard. Mater. 2021, 414, 125603. [CrossRef]

34. Herrmann, J.M. Heterogeneous photocatalysis: Fundamentals and applications to the removal of various types of aqueous pollutants. Catal. Today 1999, 53, 115-129. [CrossRef]

35. Malato, S.; Fernández-Ibáñez, P.; Maldonado, M.I.; Blanco, J.; Gernjak, W. Decontamination and disinfection of water by solar photocatalysis: Recent overview and trends. Catal. Today 2009, 147, 1-59. [CrossRef]

36. Aliste, M.; Pérez-Lucas, G.; Vela, N.; Garrido, I.; Fenoll, J.; Navarro, S. Solar-driven photocatalytic treatment as sustainable strategy to remove pesticide residues from leaching water. Environ. Sci. Pollut. Res. Int. 2020, 27, 7222-7233. [CrossRef]

37. Herrmann, J.M. Photocatalysis fundamentals revisited to avoid several misconceptions. Appl. Catal. B Environ. 2010, 99, 461-468. [CrossRef]

38. Pirisi, F.M.; Cabras, P.; Garau, V.L.; Melis, M.; Secchi, E. Photodegradation of Pesticides. Photolysis Rates and Half-Life of Pirimicarb and Its Metabolites in Reactions in Water and in Solid Phase. J. Agric. Food Chem. 1996, 44, 2417-2422. [CrossRef]

39. Wang, J.; Wang, S. Activation of persulfate (PS) and peroxymonosulfate (PMS) and application for the degradation of emerging contaminants. Chem. Eng. J. 2018, 334, 1502-1517. [CrossRef]

40. Matzek, L.W.; Carter, K.E. Activated persulfate for organic chemical degradation: A review. Chemosphere 2016, 151, 178-188. [CrossRef]

41. Yang, Q.; Ma, Y.; Chen, F.; Yao, F.; Sun, J.; Wang, S.; Yi, K.; Hou, L.; Li, X.; Wang, D. Recent advances in photo-activated sulfate radical-advanced oxidation process (SR-AOP) for refractory organic pollutants removal in water. Chem. Eng. J. 2019, 378, 122149. [CrossRef]

42. Quiroz, M.A.; Bandala, E.R.; Martínez-Huitle, C.A. Advanced Oxidation Processes (AOPs) for removal of pesticides from aqueous media. In Pesticides-Formulations, Effects, Fate; Stoytcheva, M., Ed.; InTechOpen: London, UK, 2011; pp. 685-705. Available online: https:/ / www.intechopen.com/books/pesticides-formulations-effects-fate/advanced-oxidation-processes-aops-forremoval-of-pesticides-from-aqueous-media (accessed on 25 February 2021).

43. Vela, N.; Fenoll, J.; Garrido, I.; Pérez-Lucas, G.; Flores, P.; Hellín, P.; Navarro, S. Reclamation of agro-wastewater polluted with pesticide residues using sunlight activated persulfate for agricultural reuse. Sci. Total Environ. 2019, 660, 923-930. [CrossRef]

44. Fenoll, J.; Garrido, I.; Cava, J.; Hellín, P.; Flores, P.; Navarro, S. Photometabolic pathways of chlorantraniliprole in aqueous slurries containing binary and ternary oxides of $\mathrm{Zn}$ and Ti. Chem. Eng. J. 2015, 264, 720-727. [CrossRef]

45. Aliste, M.; Garrido, I.; Flores, P.; Hellín, P.; Vela, N.; Navarro, S.; Fenoll, J. Reclamation of agro-wastewater polluted with thirteen pesticides by solar photocatalysis to reuse in irrigation of greenhouse lettuce grown. J. Environ. Manag. 2020, $266,110565$. [CrossRef] [PubMed]

46. Fenoll, J.; Hellín, P.; Martinez, C.M.; Flores, P.; Navarro, S. Semiconductor-sensitized photodegradation of s-triazine and chloroacetanilide herbicides in leaching water using $\mathrm{TiO}_{2}$ and $\mathrm{ZnO}$ as catalyst under natural sunlight. J. Photochem. Photobiol. A Chem. 2012, 238, 81-87. [CrossRef]

47. Fenoll, J.; Hellín, P.; Martinez, C.M.; Flores, P.; Navarro, S. Semiconductor oxides-sensitized photodegradation of fenamiphos in leaching water under natural sunlight. Appl. Catal. B. 2012, 115-116, 31-37. [CrossRef]

48. Armstrong, D.A.; Huie, R.E.; Koppenol, W.H.; Lymar, S.V.; Merényi, G.; Neta, P.; Ruscic, B.; Stanbury, D.M.; Steenken, S.; Wardman, P. Standard electrode potentials involving radicals in aqueous solution: Inorganic radicals (IUPAC Technical Report). Pure Appl. Chem. 2015, 87, 1139-1150. [CrossRef]

49. Konstantinou, I.K.; Zarkadis, A.K.; Albanis, T.A. Photodegradation of selected herbicides in various natural waters and soils under environmental conditions. J. Environ. Qual. 2001, 30, 121-130. [CrossRef] [PubMed]

50. Ren, M.; Drosos, M.; Frimmel, F.H. Inhibitory effect of NOM in photocatalysis process: Explanation and resolution. Chem. Eng. J. 2018, 334, 968-975. [CrossRef]

51. Liqing, Z.; Guoguang, L.; Dezhi, S.; Kun, Y. Hydrolysis of thiamethoxam. Bull. Environ. Contam. Toxicol. 2006, 76, 942-949. [CrossRef]

52. Lewis, K.A.; Tzilivakis, J.; Warner, D.J.; Green, A. An international database for pesticide risk assessments and management. Hum. Ecol. Risk Assess. 2016, 22, 1050-1064. [CrossRef] 
53. Fenoll, J.; Vela, N.; Garrido, I.; Pérez-Lucas, G.; Navarro, S. Abatement of spinosad and indoxacarb residues in pure water by photocatalytic treatment using binary and ternary oxides of Zn and Ti. Environ. Sci. Pollut. Res. 2014, 21, 12143-12153. [CrossRef]

54. Fenoll, J.; Hellín, P.; Martínez, C.M.; Flores, P.; Navarro, S. Determination of 48 pesticides and their main metabolites in water samples by employing sonication and liquid chromatography-tandem mass spectrometry. Talanta 2011, 85, 975-982. [CrossRef] [PubMed]

55. Fenoll, J.; Garrido, I.; Hellín, P.; Flores, P.; Navarro, S. Photodegradation of neonicotinoid insecticides in water by semiconductor oxides. Environ. Sci. Pollut. Res. 2015, 22, 15055-15066. [CrossRef] [PubMed]

56. Boesten, J.J.T.I.; Aden, K.; Beigel, C.; Beulke, S.; Dust, M.; Dyson, J.S.; Fomsgaard, I.S.; Jones, R.L.; Karlsson, S.; van der Linden, A.M.A.; et al. Guidance Document on Estimating Persistence and Degradation Kinetics from Environmental Fate Studies on Pesticides in EU Registration. The Final Report of the Work Group on Degradation Kinetics of FOCUS (FOrum for the Co-ordination of Pesticide Fate Models and Their USe). EC Document Reference Sanco/10058/2005 Version 2.0. Brussels, 2006 Available online: https:/ / esdac.jrc.ec.europa.eu/public_path/projects_data/focus/dk/docs/finalreportFOCDegKinetics.pdf (accessed on 18 January 2021). 